\title{
Supreme Court mulls delay of assisted-dying law
}

A $\mathrm{t}$ a Supreme Court of Canada hearing Jan. 11, the federal government argued that it couldn't meet the Feb. 6 deadline for drafting doctor-assisted dying legislation and asked for a six-month extension. The appellants countered that the federal role in the legislation is relatively minor and that the law should come into effect immediately.

The Supreme Court reserved judgment after a 90-minute hearing of oral arguments from four parties regarding the federal government's request for the extension.

The extension concerns the landmark Carter v. Canada ruling on Feb. 6, 2015, in which the Supreme Court struck down the Criminal Code of Canada ban on physician-assisted dying on the grounds that it violated Canadians' charter rights. It thus gave Canadian adults who are mentally competent and suffering intolerably and enduringly the right to a doctor's help in dying. The justices suspended their decision for a year to give federal and provincial governments time to amend laws. The ruling is currently slated to come into effect Feb. 6, 2016, unless the federal government is successful in getting an extension.

Robert Frater, the lawyer representing the Attorney General of Canada, said the request for an extension was prompted by the complexity of the issues at stake, as outlined in the 43 recommendations contained in the Nov. 30 Provincial-Territorial Expert Advisory Group Report on Physicianassisted Dying.

These issues include assessing eligibility, reporting mechanisms, processes for access and conscientious objectors, overview and review, health professional education and training, and public education and engagement. The report "acknowledges that the provinces should be asking the federal government for further clarity in the Criminal Code," Frater told the court.

"The federal government has to do

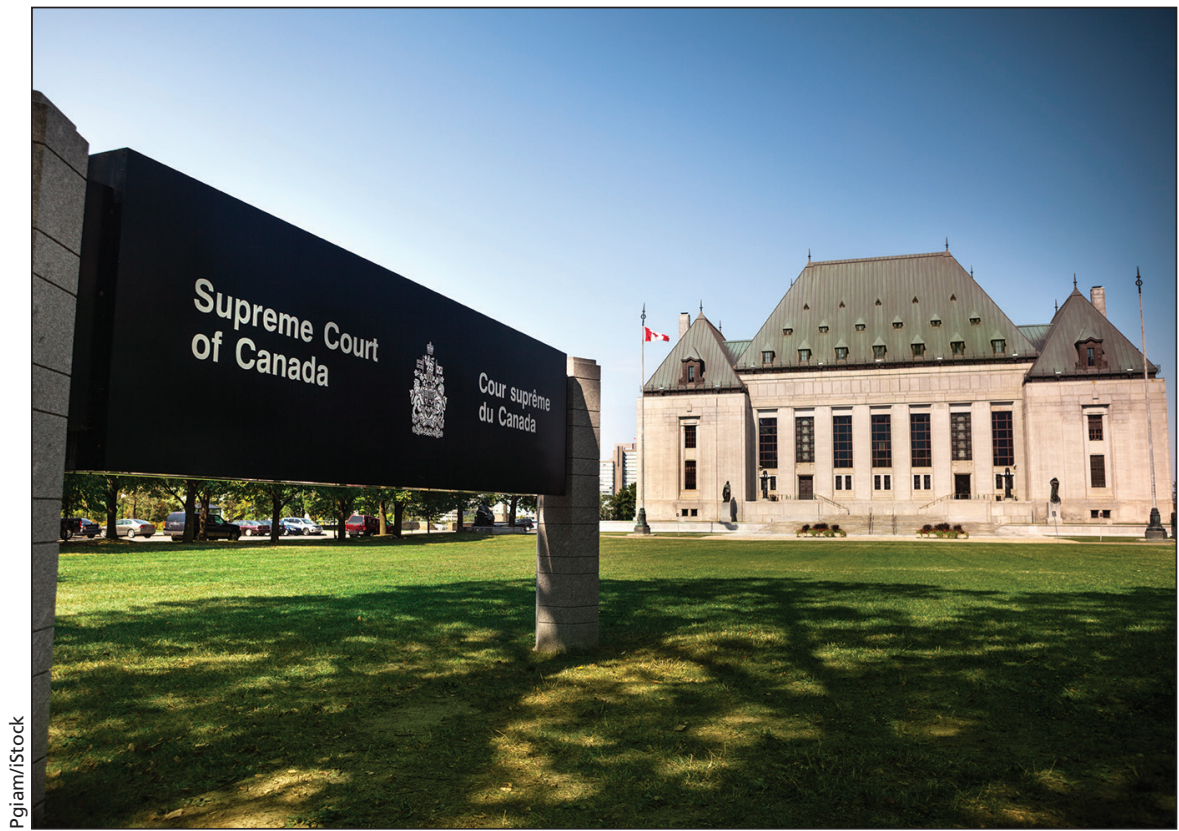

The federal government asked the Supreme Court of Canada for a six-month extension for drafting physician-assisted dying legislation.

something to allow provinces scope to act," he said.

The Supreme Court justices pursued a line of questioning about the ramifications of the recent Quebec Court of Appeal ruling that consumed almost half of Frater's allotted 30 minutes. Quebec doesn't have to wait for Criminal Code amendments before implementing its law on physician-assisted dying. Its law, which came into effect Dec. 10, is similar to the provisions in the Carter case except that it is reserved for people at the end of life.

Frater said he is not opposed to the Quebec exemption. "Only in Quebec has a comprehensive scheme in place." However, he said, the exemption will last only until the federal legislation is enacted. It will give "clarity to permit the Quebec scheme to be the same or to change. It depends on what Parliament decides to do."

Lawyer Jean-Yves Bernard, representing the procureure générale du Quebec, likewise spoke in favour of an exemption but also made a case for Quebec's rules to stand. "From Quebec's point of view, the [new] legislation is a law to do with medical care. It has nothing to do with the Criminal Code." $\mathrm{He}$ added that it is part of the continuum of care that includes palliative care and is "squarely in the provincial jurisdiction, so the Criminal Code doesn't apply."

Bernard argued against an extension for the federal government: "There should be nothing to prevent this ruling from moving forward."

He wasn't alone in this view. Lawyer Joseph Arvay, representing the appellants in the original Carter et al. case, said that of the 43 recommendations in the provincial/territorial expert report, only four required federal action: whether mature minors should be allowed to apply for physicianassisted suicide; how to protect the doctor and health care team; whether the law should be extended to allow nurseassisted dying; and whether the law should be extended to people who are not competent at the time of request.

Arvay argued that these factors are not sufficient to justify a delay. "Parliament can at its leisure address these 
issues," he told the court. "On the other side the equation is that we have really suffering people ..."

The Supreme Court's ruling in the Carter case provided sufficient guidance to protect the public, he argued. And Parliament may or may not need to amend the Criminal Code, he added. Even if they do, that "doesn't justify suspension."

“After Carter, it's clear physicians are now allowed to assist in taking a life so long as these provisions [in the ruling] are met."

Arvay said he is not even sure the ruling needed to be suspended for a year in the first place.

Malliha Wilson, a lawyer representing the attorney general of Ontario, supported the federal bid for an extension, as did the Canadian Medical Association (CMA). In a Dec. 22 statement, the CMA wrote that the "additional time will allow for more understanding of the scope and implications of the critical components of the legislative regime and framework for assisted dying." According to the doctors' association, the Carter decision raised complex issues with implications for both medical practice and policy. The extension will give CMA time to create "communication materials, programming and supports" doctors need.

\section{Progress in stops and starts}

In the wake of Carter v. Canada, progress on new federal and provincial-territorial laws to regulate physicianassisted death has been uneven.

"It depends on what you see as the starting point for progress," says Jennifer Gibson, director of the University of Toronto Joint Centre for Bioethics. "We got off to a slower start than we might have. I don't think there was anticipation that the Supreme Court would rule as it did in February [2015]."

After the Carter decision, the previous Conservative federal government did nothing for five months and even voted against a Liberal motion to create a multiparty committee to draft new laws by mid-summer 2015. In July, the Conservatives appointed an advisory panel including two experts who were publicly opposed to physician-assisted death. The panel, created just two weeks before the Conservatives dissolved parliament for a marathon election campaign, delivered its report to the new Liberal government in December 2015. The recommendations are not yet public.

In December, the Liberals rushed a motion to create a joint committee of MPs and senators to craft "expedited" legislation by August 2016. But this, too, has stalled: the Senate immediately selected five members for the job but the House of Commons hasn't appointed MPs. Frater says the senate members are ready to start now and would be able to meet an extended deadline in August. "They are going to make and meet that deadline."

In the face of federal delays, provincial and territorial governments moved ahead with consistent but cautious progress, with the exception of Quebec.

"Quebec's experience shows that it's possible to build enough consensus to pass legislation," says David Solomon, a Toronto lawyer who specializes in health industry governance and regulation. That hasn't been possible in the case of other legal yet controversial services such as abortion, he notes.

Otherwise, the Quebec law provides "limited value" as a roadmap for other provinces, Solomon says. "It was engineered to withstand legal challenges to its constitutionality, so it has a lot of peculiar aspects that won't be necessary now."

For example, Quebec likely will face challenges to its requirement that all health institutions provide physician-assisted death, as well as the provision that patients must be terminally ill to receive the service (a narrower test than Carter allows).

After the Carter ruling, other provinces and territories quickly banded together to form an expert advisory group to guide the development of uniform policies and safeguards across the country.

The collaboration was "significant and very encouraging" given Canada's history of piecemeal health care access and regulation, says Gibson, who cochaired the group. "The message we received right from the get-go was the intention to avoid a patchwork across the country."

The advisory group issued recommendations in November, including that provinces and territories governments should fund physician-assisted death, and that access shouldn't be impeded by "arbitrary age limits," delineating a specific list of eligible medical conditions or imposing a "prescribed waiting/reflection period." The group also recommended that objecting physicians be required to provide patients with information and referrals for the service.

Provinces including Ontario have also launched independent public consultations on the issue. However, "it's hard to get a really good read at this point about the provinces and territories' readiness," says Gibson. "We've had a bit of a quiet period over the last six weeks but I think we're going to start seeing much more in January ... now we know what our marching orders are."

However, another member of the provincial-territorial advisory group says some governments and professional regulators may hang back until the federal government takes the lead. "There are some who may want to delay for political reasons, to cover themselves," explains Arthur Schafer, founding director of the Centre for Professional and Applied Ethics at the University of Manitoba.

Similar concerns were raised in November when BC Health Minister Terry Lake suspended a bipartisan committee's recommendations on physician-assisted death pending federal guidance.

Schafer argues that any unnecessary delay is "disrespectful to the rights of Canadians."

"There are patients now who have been diagnosed with grievous and irremediable medical conditions and whose enduring suffering is intolerable to them," he says. "So there's a very strong reason to discourage delay and a real cost in terms of human suffering." - Lauren Vogel and Barbara Sibbald, CMAJ

CMAJ 2016. DOI:10.1503/cmaj.109-5218 